\title{
Trace Elements Analysis in Drinking Water of Meghalaya by Using Graphite Furnace-Atomic Absorption Spectroscopy and in relation to Environmental and Health Issues
}

\author{
Elarina N. Dkhar, ${ }^{1}$ Paul S. Dkhar, ${ }^{2}$ and Jasha Momo H. Anal ${ }^{2}$ \\ ${ }^{1}$ Physics Department, Shillong College, Laitumkhrah, Shillong, Meghalaya 793003, India \\ ${ }^{2}$ Elemental Analysis Section, Sophisticated Analytical Instrument Facility, North Eastern Hill University, Shillong, \\ Meghalaya 793022, India \\ Correspondence should be addressed to Jasha Momo H. Anal; hmunsjasha@gmail.com
}

Received 31 May 2013; Revised 31 October 2013; Accepted 31 October 2013; Published 29 January 2014

Academic Editor: Daryoush Afzali

Copyright (C) 2014 Elarina N. Dkhar et al. This is an open access article distributed under the Creative Commons Attribution License, which permits unrestricted use, distribution, and reproduction in any medium, provided the original work is properly cited.

\begin{abstract}
Determination of the certain major and trace elements was carried out in drinking water supply scheme in three districts of Meghalaya. This work aims to identify trends resulting in the deterioration of drinking water which is also a potential source of environmental contaminants. About 50 samples, each from one district, were collected both from the source and various tanks and tap. The elements determined are $\mathrm{Li}, \mathrm{Na}, \mathrm{Cr}, \mathrm{Mn}, \mathrm{Fe}, \mathrm{Co}, \mathrm{Ni}, \mathrm{Cu}, \mathrm{Zn}, \mathrm{As}, \mathrm{Rb}, \mathrm{Ag}, \mathrm{Au}, \mathrm{Pb}, \mathrm{Cd}, \mathrm{Se}, \mathrm{Ca}, \mathrm{K}$, and $\mathrm{Mg}$. The pH is slightly lower than neutral $\mathrm{pH}$ of 7 while the turbidity is very high even after treatment. The concentrations of Ca and $\mathrm{Mg}$ are found to be deficient. The elements $\mathrm{Cr}, \mathrm{Fe}, \mathrm{Co}, \mathrm{Ni}, \mathrm{Zn}, \mathrm{Mo}$, and $\mathrm{Pb}$ decrease after treatment while $\mathrm{Mn}, \mathrm{Cu}$, and $\mathrm{Cd}$ increase slightly after treatment. Se concentration is found to be much higher than expected. The results were compared with the standard recommendation values for the quality of drinking water. This study provides a general indication of where water-quality constituent concentrations met or exceeded water-quality standards and the data presented in this report will be useful from public health point of view.
\end{abstract}

\section{Introduction}

Human life without water is just impossible. Water is not only required for metabolic systems in human body but also required for other associated activities with human life. The specifications of water required for different purposes are different. Distilled water for laboratory, medical factories, minerals in drinking water, industries, agricultural, aquatic cultures, and so forth all are diverse. Human body is approximately $70-80 \%$ water by weight, with $99.5 \%$ of all molecules containing water [1]. Water is the delivery system that carries nutrients to the cells, maintains energy production, and removes toxic wastes from the body. Biological processes including circulation, digestion, absorption, and excretion depend on water to function properly.

Water quality varies from source to source which are largely influenced by natural and human factors. One of the factors is that the levels of various trace elements and compounds in available water supplies vary, due to a difference in geological and geographical factors and also sometimes due to a difference in chemical treatment before supply. Though these trace elements often seem to be very insignificant, they do have an important role in life. The characteristic properties of a complex system and many interesting problems that arise in different spheres are derived or can be explained from the absence or the presence of specific element at these low levels of concentration. So, identification and qualification of these elements become necessary. The harmful action of different element is different. If it crosses the limit, it may develop severe diseases for human, animals, and plants and sometimes may cause death. Chromium reduces fatty acids and cholesterol and regulates sugar and insulin rates in the blood, but chronic exposure to high chromium levels causes lung cancer in human [2]. 
Most water quality regulations pertaining to drinking water such as maximum contaminant levels (MCLs) and treatment technique requirements for microbial and chemical contaminants are applied before or at the point where water enters the distribution system. Epidemiological studies and outbreak investigations conducted for several years suggest that a substantial proportion of waterborne disease outbreaks, both microbial and chemical, is attributable to problems within distribution systems. In public water supply distribution systems a more sophisticated and enhanced skill for proper sample collection and preservation, as well as better understanding of aquatic chemistry and biology, is required. Also in many systems the new regulations created a shift in the use of disinfectants in the distribution systems from a relatively simple application of chlorine to rather complicated application and maintenance of chloramines [3].

Polluted water can be very dangerous for human health and cases of serious diseases are often caused by various bacteria and viruses. Toxic metals such as $\mathrm{Hg}, \mathrm{Cd}, \mathrm{As}, \mathrm{Pb}$, and $\mathrm{Ni}$ tend to accumulate in certain reservoirs (water, soils, sediments, etc.) from which they may be released by various processes of remobilization and their solubility becomes available to the biological food chain. Metallic pollution of fresh waters may take place from large scale discharge of industrial effluents into the rivers. This poses a potential health hazard for human life.

Our study is mainly the assessment of drinking water for certain major and trace elements so as to identify trends relevant to the deterioration of drinking water quality in water supply distribution systems. The available information provided a general indication of where water-quality constituent concentrations met or exceeded water-quality standards. The elements determined are $\mathrm{Na}, \mathrm{As}, \mathrm{Cu}, \mathrm{Cr}, \mathrm{Fe}$, $\mathrm{Co}, \mathrm{Ni}, \mathrm{Zn}, \mathrm{Pb}, \mathrm{Cd}, \mathrm{Se}, \mathrm{Ca}, \mathrm{K}, \mathrm{Mg}$, and $\mathrm{Mn}$. Some of the important physicochemical properties of this water such as $\mathrm{pH}$, turbidity, conductivity, phosphate, and nitrate are also presented.

\section{Material and Methods}

2.1. Reagents. All chemicals used were of analytical grade purchased from S.D. Fine-Chem Ltd. and CPA Ltd. in India. The distilled water used is ultrapure deionized water (Millipore S.A., France). The same distilled water was used for the preparation of standards, and modifier solutions. The stock standard solutions were purchased from Sigma Aldrich chemical company for calibration by preparing standard solutions.

2.2. Sample Collection. Samples of drinking water were collected in $1.5 \mathrm{~L}$ capacity polythene bottles from the source and from various tanks and taps using trace metal clean techniques. Prior to filing, the sample bottles were again rinsed two or three times with water to be collected. About fifty samples from each district were collected. Both untreated and treated drinking water were collected from different sources, tanks, and taps using standard procedures. The $\mathrm{pH}$ of each sample was also determined.
2.3. Water Plant. Treatment plant is conventional type having constant alum dosing tank placed over the raw water channeled through an automatic control valve. The conventional treatment plant consists of flush mixer, clariflocculator, and rapid sand filtration plant. The chemical used in the treatment plant is alum and lime for treatment of raw water and chlorine gas is used for disinfecting the treated water. The doses are controlled as per the raw water quality.

2.4. Water Preservation. After collecting, the water was then brought to the laboratory for preconcentration on the same day. If the samples are to be processed the next day, acidic treatment such as adding $2 \mathrm{~mL}$ of conc. $\mathrm{HCl}$ is required for preservation. On receipt at the laboratory, if the water is clean, we process directly. If turbidity persists, then we filter the samples first before processing. All the elements were detected after concentrating the samples 40-100 times by evaporation in an oven at optimal temperature.

2.5. Apparatus. An Analytik Jena AAS Vario 6 graphite furnace spectrometer furnished with PC-controlled 6-piece lamp turret and argon gas supply was used for all of the absorption measurements. The hollow cathode lamps were fitted for specific element that has to be analyzed with their respective wavelength and the slit width was adjusted accordingly. Signal measurement was done in peak area and calibration was in linear mode. The sample injection volume is $20 \mu \mathrm{L}$. The typical heating program of GF-AAS is drying (injection of the sample into the filter furnace), pyrolysis, atomization, and cleansing. The elements instrumental conditions are given in Table 1 [4]. Conductivity was measured using Conductivity Meter (model 304, Systronics, India). The total nitrate and phosphate was determined by APHA methods. The $\mathrm{pH}$ measurements were carried out by a digital pH meter (model 802, Systronics, India) and the turbidity was measured with nephelometer (model 131 Systronics, India). All glassware and containers were soaked in $1.4 \mathrm{~mol} \mathrm{~L}^{-1}$ nitric acid for at least 24 hours and rinsed three times with water before use.

2.6. Statistical Method. Correlation study was adopted to determine the relationship between the trace elements using a Microsoft Excel software package.

\section{Results and Discussion}

It is evident from Table 2 that measurement of $\mathrm{pH}$, turbidity, phosphate, and nitrate gives first hand information of water quality which is a frequently used test in water chemistry. In our analysis, the $\mathrm{pH}$ of raw and treated water ranges from 6.5 to 7.3; this is within the limit (Table 4). The $\mathrm{pH}$ of water indicates the degree of acidity or alkalinity of water and has a significant influence on the reaction of coagulants with raw water. It is also the most important water quality factor controlling levels of these metals in treated water. The turbidity of raw water is 56.24 and 10.27 NTU for treated water. This is very high compared with the standard methods. Raw water which is low in colour and higher turbidity 
TABLE 1: AAS Vario-6 graphite furnace elements instrumental analytical conditions.

\begin{tabular}{|c|c|c|c|c|c|c|}
\hline Elements & $\begin{array}{c}\text { Wavelength } \\
(\mathrm{nm})\end{array}$ & $\begin{array}{l}\text { Slit width } \\
(\mathrm{nm})\end{array}$ & $\begin{array}{l}\text { Atomization } \\
\text { temp. }\left(0^{\circ} \mathrm{C}\right)\end{array}$ & Matrix modifiers & $\begin{array}{l}\text { Interference } \\
\text { wavelength }(\mathrm{nm})\end{array}$ & Contamination \\
\hline $\mathrm{Li}$ & 670.8 & 0.8 & $2250-2300$ & - & - & Possible \\
\hline $\mathrm{Na}$ & 589.0 & 0.5 & $1400-1450$ & - & - & - \\
\hline $\mathrm{Cr}$ & 357.9 & 0.8 & $2100-2200$ & $\mathrm{NH}_{4} \mathrm{H}_{2} \mathrm{PO}_{4}$ & $\mathrm{Fe} 358.1, \mathrm{Nb} 358.0$ & - \\
\hline $\mathrm{Mn}$ & 279.5 & 0.2 & $1600-1650$ & $\mathrm{Mg}\left(\mathrm{NO}_{3}\right)_{2}+\mathrm{Pd}\left(\mathrm{NO}_{3}\right)_{2}$ & $\begin{array}{l}\mathrm{Mg} 279.5, \text { Fe 279.5, } \\
\mathrm{Pb} 280.2\end{array}$ & Possible \\
\hline $\mathrm{Fe}$ & 248.3 & 0.2 & $1850-2050$ & $\mathrm{Mg}\left(\mathrm{NO}_{3}\right)_{2}$ & & $\begin{array}{c}\text { Depressions by } \mathrm{Al} \\
\text { and Si signal possible }\end{array}$ \\
\hline Co & 240.7 & 0.2 & $2000-2100$ & $\mathrm{Mg}\left(\mathrm{NO}_{3}\right)_{2}$ & - & - \\
\hline $\mathrm{Ni}$ & 232.0 & 0.2 & $2100-2300$ & $\mathrm{Mg}\left(\mathrm{NO}_{3}\right)_{2}$ & - & - \\
\hline $\mathrm{Cu}$ & 324.8 & 0.8 & $1800-1900$ & - & $\begin{array}{l}\text { Ni 324.3, Mn 324.9, } \\
\text { Pd 324.3, Ag 324.8, } \\
\text { Eu 324.8 }\end{array}$ & Possible \\
\hline $\mathrm{Zn}$ & 213.9 & 0.8 & $1000-1100$ & $\mathrm{Pd}\left(\mathrm{NO}_{3}\right)_{2}$ & $\begin{array}{l}\mathrm{Cu} 213.9, \mathrm{Te} 214.3 \\
\text { As } 214.4, \mathrm{Fe} 213.6 \\
\mathrm{Fe} 213.9\end{array}$ & Possible \\
\hline As & 193.7 & 0.8 & $2050-2250$ & $\mathrm{Ni}\left(\mathrm{NO}_{3}\right)_{2}$ & - & - \\
\hline $\mathrm{Se}$ & 196.0 & 1.2 & $1750-1900$ & $\mathrm{Ni}\left(\mathrm{NO}_{3}\right)_{2}$ & - & - \\
\hline $\mathrm{Rb}$ & 780.0 & 1.2 & $1450-1700$ & - & - & - \\
\hline Mo & 313.3 & 0.8 & $2550-2600$ & $\mathrm{Mg}\left(\mathrm{NO}_{3}\right)_{2}$ & - & $\begin{array}{c}\text { Formation of carbide } \\
\text { typical }\end{array}$ \\
\hline $\mathrm{Ag}$ & 328.1 & 0.8 & $1150-1350$ & $\mathrm{NH}_{4} \mathrm{H}_{2} \mathrm{PO}_{4}$ & $\begin{array}{l}\text { Rh 328.1, Zn 328.2, } \\
\text { Cu 327.4, Y } 328.9\end{array}$ & Possible \\
\hline $\mathrm{Cd}$ & 228.8 & 0.8 & $900-1200$ & $\mathrm{NH}_{4} \mathrm{H}_{2} \mathrm{PO}_{4}+\mathrm{Mg}\left(\mathrm{NO}_{3}\right)_{2}$ & As 228.9, Fe 228.8 & - \\
\hline $\mathrm{Au}$ & 242.8 & 0.8 & $2340-2350$ & $\mathrm{Mg}\left(\mathrm{NO}_{3}\right)_{2}$ & Sn 242.1, Co 242.5 & $\begin{array}{l}\text { Depression by } \mathrm{Pt} \text { and } \\
\text { Pd signal are possible }\end{array}$ \\
\hline $\mathrm{Pb}$ & 217.0 & 0.5 & $1200-1350$ & $\mathrm{Pd}\left(\mathrm{NO}_{3}\right)_{2}+\mathrm{Mg}\left(\mathrm{NO}_{3}\right)_{2}$ & $\begin{array}{l}\mathrm{Cu} 216.5, \mathrm{Fe} 216.7 \\
\text { Ni } 216.6, \text { Sb 217.6, } \\
\text { Pt } 216.5\end{array}$ & Possible \\
\hline $\mathrm{Ca}$ & 422.7 & 1.2 & $2350-2500$ & - & - & - \\
\hline $\mathrm{Mg}$ & 285.2 & 0.8 & $1500-1650$ & - & - & - \\
\hline $\mathrm{K}$ & 766.5 & 1.2 & $1450-1600$ & - & - & - \\
\hline
\end{tabular}

brings somewhat different demands. The flocculation system must be capable of handling heavy floc and large amount of turbidity-laden floc which settle out and cause operation problems. So removal and disposal must also be given special consideration. The concentration of nitrate in raw and treated water is found to be 0.03 and $0.01 \mathrm{mg} / \mathrm{L}$. Nitrate levels may be important under certain conditions although the relative source contribution from drinking water is expected to be a maximum of about $1-2 \mathrm{mg} / \mathrm{L}$. Numerous papers have focused on the impact of nitrate in drinking water. Nitrate may be reduced to nitrite in the low $\mathrm{pH}$ environment of the stomach, reacting with amines and amides to form $\mathrm{N}$-nitroso compounds which have been linked to different types of cancer [3]. The phosphate content in raw and treated water is found to be 0.44 and $0.04 \mathrm{mg} / \mathrm{L}$. However; in low alkaline water, control strategies are sometimes utilized such as adding phosphate to reduce $\mathrm{Pb}$ and $\mathrm{Cu}$ corrosion and release of Fe from pipes scales. Table 3 presents the result of raw and treated water. The salient features of analysis for each element are given below.
Lithium. This element is detected only in Jaintia Hills district with concentration of $0.01 \mathrm{ppm}$. The element is used in the prophylaxis of bipolar depressive disorder in augmentation treatment of depression and in the therapy of some cases of unipolar depression. Lithium affects cell function via its inhibitory action on ATPase activity [5].

Sodium. The concentration of sodium detected in both raw and treated water was 135.6 and $142.3 \mathrm{ppm}$. No health baseguidelines value for this element is proposed but excess of sodium above $200 \mathrm{ppm}$ may give rise to unacceptable taste. No concrete evidence can be drawn of possible association between sodium in drinking water and occurrence of hypertension [6].

Chromium. Chromium may be present in water in both hexavalent and trivalent state. The standards (Table 4) recommend a mandatory limit of $0.05 \mathrm{ppm}$ for hexavalent $\mathrm{Cr}$ in drinking water. We could not estimate hexavalent and trivalent $\mathrm{Cr}$ separately by AAS. The highest concentration 
TABLE 2: Parameters analyzed in treated and untreated water.

\begin{tabular}{lcccc}
\hline Parameters for water analysis & Sample & East Khasi Hills & West Khasi Hills & Jaintia Hills \\
\hline \multirow{2}{*}{ pH } & Untreated water & $6.80 \pm 0.018$ & $6.60 \pm 0.031$ & $7.10 \pm 0.044$ \\
& Treated Water & $7.50 \pm 0.045$ & $7.30 \pm 0.028$ & $7.10 \pm 0.031$ \\
Turbidity NTU & Untreated water & $64.24 \pm 2.14$ & $59.80 \pm 4.18$ \\
& Treated Water & $10.25 \pm 0.45$ & $8.40 \pm 0.18$ & $12.16 \pm 0.26$ \\
Conductivityat $25^{\circ} \mathrm{C}$ with 0.01 M & Untreated water & $1.00 \pm 0.088$ & $1.20 \pm 0.048$ & $0.80 \pm 0.018$ \\
& Treated Water & $1.50 \pm 0.020$ & $0.03 \pm 0.005$ & $1.50 \pm 0.025$ \\
$\mathrm{NO}_{3}{ }^{-}(\mathrm{mg} / \mathrm{L})$ & Untreated water & $0.03 \pm 0.001$ & $0.02 \pm 0.005$ & $0.04 \pm 0.003$ \\
$\mathrm{PO}_{4}{ }^{2-}(\mathrm{mg} / \mathrm{L})$ & Treated Water & $0.01 \pm 0.006$ & $0.52 \pm 0.018$ & $0.02 \pm 0.009$ \\
& Untreated water & $0.55 \pm 0.058$ & $0.02 \pm 0.002$ & $0.02 \pm 0.078$ \\
\hline
\end{tabular}

Results are mean \pm SD of 25 observations each.

TABLE 3: Concentrations of trace elements in ppm found in (raw) untreated and treated water.

\begin{tabular}{|c|c|c|c|c|c|c|}
\hline \multirow{2}{*}{ Elements } & \multicolumn{3}{|c|}{ Untreated water } & \multicolumn{3}{|c|}{ Treated water } \\
\hline & $\mathrm{EKH}$ & WKH & $\mathrm{JH}$ & $\mathrm{EKH}$ & WKH & $\mathrm{JH}$ \\
\hline $\mathrm{Li}$ & ND & ND & $0.01 \pm 0.007$ & ND & ND & $0.01 \pm 0.002$ \\
\hline $\mathrm{Na}$ & $142 \pm 2.60$ & $140 \pm 5.15$ & $125 \pm 5.06$ & $143 \pm 4.36$ & $145 \pm 6.33$ & $139 \pm 8.53$ \\
\hline $\mathrm{Cr}$ & $0.05 \pm 0.004$ & $0.03 \pm 0.001$ & $0.02 \pm 0.009$ & $0.02 \pm 0.002$ & $0.01 \pm 0.009$ & $0.02 \pm 0.002$ \\
\hline Mn & $0.03 \pm 0.006$ & $0.02 \pm 0.003$ & $0.04 \pm 0.008$ & $0.04 \pm 0.002$ & $0.04 \pm 0.008$ & $0.03 \pm 0.006$ \\
\hline $\mathrm{Fe}$ & $0.29 \pm 0.003$ & $0.10 \pm 0.001$ & $0.16 \pm 0.001$ & $0.18 \pm 0.003$ & $0.09 \pm 0.001$ & $0.12 \pm 0.001$ \\
\hline Co & $0.08 \pm 0.004$ & $0.05 \pm 0.002$ & $0.05 \pm 0.007$ & $0.02 \pm 0.003$ & $0.03 \pm 0.007$ & $0.03 \pm 0.007$ \\
\hline $\mathrm{Ni}$ & $0.07 \pm 0.006$ & $0.04 \pm 0.004$ & $0.06 \pm 0.007$ & $0.02 \pm 0.006$ & $0.01 \pm 0.008$ & $0.03 \pm 0.004$ \\
\hline $\mathrm{Cu}$ & $0.02 \pm 0.002$ & $0.01 \pm 0.004$ & $0.02 \pm 0.006$ & $0.10 \pm 0.005$ & $0.30 \pm 0.004$ & $0.12 \pm 0.008$ \\
\hline $\mathrm{Zn}$ & $0.43 \pm 0.02$ & $0.12 \pm 0.008$ & $0.16 \pm 0.07$ & $0.14 \pm 0.003$ & $0.12 \pm 0.007$ & $0.30 \pm 0.002$ \\
\hline As & ND & ND & ND & ND & ND & ND \\
\hline $\mathrm{Se}$ & $1.53 \pm 0.08$ & $1.66 \pm 0.02$ & $1.95 \pm 0.03$ & $0.44 \pm 0.06$ & $0.54 \pm 0.002$ & $1.25 \pm 0.05$ \\
\hline $\mathrm{Rb}$ & ND & ND & ND & ND & ND & ND \\
\hline Mo & $0.07 \pm 0.006$ & $0.08 \pm 0.004$ & $0.08 \pm 0.001$ & $0.02 \pm 0.009$ & $0.04 \pm 0.002$ & $0.01 \pm 0.007$ \\
\hline $\mathrm{Ag}$ & ND & ND & ND & ND & ND & ND \\
\hline $\mathrm{Cd}$ & $0.02 \pm 0.004$ & ND & ND & $0.02 \pm 0.004$ & $0.08 \pm 0.008$ & $0.06 \pm 0.002$ \\
\hline $\mathrm{Au}$ & ND & ND & ND & ND & ND & ND \\
\hline $\mathrm{Pb}$ & $0.12 \pm 0.003$ & $0.10 \pm 0.009$ & $0.06 \pm 0.006$ & $0.04 \pm 0.004$ & $0.02 \pm 0.007$ & $0.04 \pm 0.006$ \\
\hline $\mathrm{Ca}$ & $1.74 \pm 0.02$ & $0.24 \pm 0.04$ & $0.26 \pm 0.04$ & $10.34 \pm 0.53$ & $11.71 \pm 0.10$ & $8.52 \pm 0.14$ \\
\hline $\mathrm{Mg}$ & $2.25 \pm 0.06$ & $1.40 \pm 0.09$ & $1.87 \pm 0.03$ & $5.76 \pm 0.82$ & $1.50 \pm 0.06$ & $1.20 \pm 0.02$ \\
\hline $\mathrm{K}$ & $4.30 \pm 0.13$ & $1.20 \pm 0.09$ & $2.57 \pm 0.03$ & $6.39 \pm 0.10$ & $1.42 \pm 0.03$ & $1.92 \pm 0.30$ \\
\hline
\end{tabular}

Results are mean \pm SD of 25 observations each; ND: not detectable; EKH: East Khasi Hills; WKH: West Khasi Hills; JH: Jaintia Hills.

of total $\mathrm{Cr}$ in raw water is $0.03 \mathrm{ppm}$. After treatment, the concentration reduces to $0.01 \mathrm{ppm}$. Numerous reports on its toxic effects in man and in animal are available. Chronic exposure to high chromium levels causes lung cancer in man, liver and kidney damage in animals, and skin irritation [7]. However, chromium supplementation lowers glucose, lipid levels in elderly diabetics [8].

Manganese. Mn concentration in the samples analyzed was 0.03 ppm in raw water. After treatment, the concentration of this element increases slightly to $0.05 \mathrm{ppm}$ which still falls within the limit of drinking water (Table 4). The function of this element in human is not fully understood, yet for plants it is very important. Manganese is also known to be essential for growth, reproduction and skeletal (cartilage) development of many animal species including man [9], nitrogen and inorganic acid metabolism, carbon dioxide assimilation, carbohydrates breakdown, and formation of carotene [7].

Iron. The nonmandatory, but recommended, upper limit for Fe according to the IS, USEPA (Table 4), Drinking Water Standards is $0.3 \mathrm{ppm}$. The concentration of Fe in raw water was found to be $0.18 \mathrm{ppm}$. After treatment the concentration slightly reduces to $0.13 \mathrm{ppm}$. This value falls within the limit of $0.3-1.0 \mathrm{ppm}$, which is acceptable for drinking water. A bitter-sweet stringent taste is detectable at a level of $1 \mathrm{mg} / \mathrm{L}$. This element is vital for living system and constituents of 
TABLE 4: Water quality guideline for domestic uses.

\begin{tabular}{|c|c|c|c|c|c|c|c|}
\hline Elements & $\begin{array}{c}\text { ICMR } \\
\text { standards } 1975\end{array}$ & $\begin{array}{c}\text { Indian } \\
\text { standards } 1983\end{array}$ & $\begin{array}{c}\text { WHO } \\
\text { standards } 1993\end{array}$ & $\begin{array}{c}\text { European } \\
\text { standards } 2000\end{array}$ & $\begin{array}{c}\text { USEPA } \\
\text { standards } 1996\end{array}$ & $\begin{array}{c}\text { Untreated } \\
\text { water }\end{array}$ & Treated water \\
\hline $\mathrm{Li}$ & - & - & - & - & - & ND & ND \\
\hline $\mathrm{Na}$ & $\leq 200$ & 200 & $\leq 200$ & 10.0 & - & $135.6 \pm 4.27$ & $142.3 \pm 6.40$ \\
\hline $\mathrm{Cr}$ & 0.05 & 0.05 & 0.05 & 0.05 & 0.05 & $0.03 \pm 0.004$ & $0.01 \pm 0.004$ \\
\hline $\mathrm{Mn}$ & 0.05 & 0.10 & 0.50 & 0.01 & 0.05 & $0.03 \pm 0.005$ & $0.05 \pm 0.004$ \\
\hline $\mathrm{Fe}$ & 0.03 & 0.3 & 0.30 & 0.01 & 0.03 & $0.18 \pm 0.003$ & $0.13 \pm 0.001$ \\
\hline Co & - & - & - & - & - & $0.06 \pm 0.004$ & $0.02 \pm 0.003$ \\
\hline $\mathrm{Ni}$ & - & - & 0.02 & 0.02 & & $0.05 \pm 0.005$ & $0.02 \pm 0.006$ \\
\hline $\mathrm{Cu}$ & $\leq 1.0$ & 1.00 & 1.50 & 2.00 & 1.00 & $0.01 \pm 0.004$ & $0.17 \pm 0.005$ \\
\hline $\mathrm{Zn}$ & $\leq 5.0$ & 5.0 & 0.05 & - & - & $0.23 \pm 0.03$ & $0.18 \pm 0.004$ \\
\hline As & 0.05 & 0.05 & 0.01 & 0.005 & 0.01 & ND & ND \\
\hline $\mathrm{Se}$ & 0.01 & 0.01 & - & 0.01 & 0.05 & $1.71 \pm 0.04$ & $0.74 \pm 0.03$ \\
\hline $\mathrm{Rb}$ & - & - & - & - & - & & \\
\hline Mo & - & - & 0.07 & - & - & $0.07 \pm 0.003$ & $0.02 \pm 0.006$ \\
\hline $\mathrm{Ag}$ & - & - & 0.005 & - & - & ND & $\mathrm{ND}$ \\
\hline $\mathrm{Cd}$ & 0.005 & 0.01 & 0.01 & 0.05 & 0.01 & $0.02 \pm 0.004$ & $0.05 \pm 0.004$ \\
\hline $\mathrm{Au}$ & - & - & - & - & - & $\mathrm{ND}$ & $\mathrm{ND}$ \\
\hline $\mathrm{Pb}$ & 0.01 & 0.10 & 0.01 & 0.02 & 0.05 & $0.09 \pm 0.006$ & $0.03 \pm 0.005$ \\
\hline $\mathrm{Ca}$ & - & 75 & 100 & 100 & 100 & $0.74 \pm 0.03$ & $10.19 \pm 0.25$ \\
\hline $\mathrm{Mg}$ & - & 30 & 150 & 50 & 30 & $1.84 \pm 0.06$ & $1.82 \pm 0.30$ \\
\hline K & - & - & - & - & - & $2.69 \pm 0.08$ & $3.24 \pm 0.14$ \\
\hline $\mathrm{pH}$ & $6.5-8.5$ & $6.5-8.5$ & $6.5-8.5$ & & $6.0-8.5$ & $6.5 \pm 0.02$ & $7.3 \pm 0.03$ \\
\hline $\mathrm{PO}_{4}{ }^{2-}$ & - & - & - & - & - & $0.44 \pm 0.04$ & $0.04 \pm 0.003$ \\
\hline Nitrate & 45 & 45 & 50 & 50 & 10 & $0.03 \pm 0.003$ & $0.01 \pm 0.006$ \\
\hline Turbidity & $5-15$ & $5-15$ & 5 & & $0.5-5.0$ & & \\
\hline
\end{tabular}

Indian Standard (1983) Guidelines for Drinking Water Quality, 2nd Edition, Vol. 1, WHO.

Indian Council of Medical Research (1975) Standards for Drinking Water in India, ICMR, New Delhi.

World Health Organisation (1993) Guidelines for Drinking Water Quality-Health criteria and other supporting Information. World Health Organisation, Geneva, Switzerland

European Standard (2000) Guidelines for Drinking Water Quality.

USEPA (1996) Quality criteria for water. EPA 440/5-86-001, US Environmental Protection Agency, Washington DC, USA.

hemoglobin in blood. Deficiency of iron may cause anemia and other immunological deficiencies. Recently it has been found that high dietary iron concentration enhances the formation of cholesterol oxidizing products in liver [10].

Cobalt. The samples analyzed showed Co concentration in raw and treated water to be 0.06 and $0.02 \mathrm{ppm}$. No comparative studies could be made as the concentration recommended for this element in drinking water is not available. Cobalt is an integral part of vitamin $B_{12}$ and essential for the production of red blood cells. Its deficiency is thought to cause megaloblastic anemia called pernicious anemia [11]. Salts of cobalt such as acetate, chloride, and sulphates are highly toxic to human beings.

Nickel. The concentration of nickel analyzed in raw water is found to be $0.05 \mathrm{ppm}$ and in treated water, it is $0.02 \mathrm{ppm}$ which is within the limit of standards (Table 4). This level being very low when compared with the standard values.
However, exposure to airborne $\mathrm{Ni}$ dust and vapours may cause lung cancer and disorders of the respiratory system [6]. Nickel is a well-known human carcinogen and it affects the activity of $\alpha$-tocopherol, the most common antioxidant in human body [11].

Copper. The IS, USEPA, Standards recommend that $\mathrm{Cu}$ shall not exceed an upper limit of $1 \mathrm{ppm}$ in acceptable water supplies (Table 4). This element is detected at concentration of $0.01 \mathrm{ppm}$ in raw water. However, the concentration increases to $0.17 \mathrm{ppm}$ after treatment. Though $\mathrm{Cu}$ is a very useful element, excess of $\mathrm{Cu}$ concentration in human causes "Wilson disease" [6]. Deficiency may lead to cardiovascular disease; excess of this element leads to hypertension. Copper is also known to have an antioxidant enzyme activity [12].

Zinc. The upper limit of $\mathrm{Zn}$ concentration permitted in acceptable water supplies is $5 \mathrm{ppm}$ (Table 4 ). On aesthetic considerations water containing even lower concentrations 
of zinc is unsuitable as the $\mathrm{Zn}$ salts cause an unpleasant taste and opalescence in alkaline waters. $\mathrm{Zn}$ content analyzed in raw water is $0.23 \mathrm{ppm}$. It slightly reduces in treated water to $0.18 \mathrm{ppm}$. Zinc deficiency can lead to reduction of normal growth and impaired bone development [12] and at higher concentration it causes poisoning in human, especially inhalation of zinc oxides fumes. Ingestion of acidic food prepared in $\mathrm{Zn}$ galvanized containers also results sometimes in an illness. Dermatitis can occur upon zinc chloride contact with skin and this element has a role in wound healing [7].

Selenium. The concentrations of this element in raw water are found to be $1.71 \mathrm{ppm}$ and in treated water $0.74 \mathrm{ppm}$. The concentration of this element reduces after treatment. The desirable IS and international standards are given to be $0.01 \mathrm{ppm}$ (Table 4). As the concentration of these elements in the soils is very high, it may be present in the soluble form where it leaches into the river water through many ways such as precipitation and sedimentation [13]. Selenium is considered as an element essential to plant life and it is present as a selenoamino similar to cysteine and leucine [7]. In human body, it occurs in the entire cell and tissues in various concentrations. When the occurrence of this element is at toxic level it leads to skin discoloration, bad teeth, and some psychological and gastrointestinal problems [14]. However, selenium appears to be a natural protective agent against heavy metal toxicity such as $\mathrm{Hg}, \mathrm{Cd}, \mathrm{Ag}$, and $\mathrm{Th}$ in biological system.

Molybdenum. The concentration of this element in raw water is $0.07 \mathrm{ppm}$ and in treated water it is found to reduce to $0.02 \mathrm{ppm}$. The guidelines value for this element is $0.07 \mathrm{ppm}$ and it is considered to be an essential element and no data are available on the carcinogenicity of this element on human beings [6].

Cadmium. In the samples analyzed in raw water, $\mathrm{Cd}$ was found to be absent in two districts except in one district which is found to be $0.02 \mathrm{ppm}$. However, this element is detected in treated water in all three districts slightly at higher concentration of $0.05 \mathrm{ppm}$. Compared with other standards (Table 4), our water samples contain slightly higher concentration after treatment which may arise due to the impurities from the chemical used to treat the water. Proper investigation should be carried out in order to correct the problem. Cadmium is reported to have toxic role in renal dysfunctions, lung damage, reproductive toxicity, and bone defects [15]. The dreadful disease known as "Itai-Itai" is the result of water contamination by cadmium from mining waste. Cadmium is biologically a nonessential element of high toxic potential [7].

Lead. The concentration of lead in raw and treated water was found to be 0.09 and $0.03 \mathrm{ppm}$. Compared with standards (Table 4), the concentration of this element is almost within the limit which is not so harmful for human consumption. However, this element is very toxic although it may be present in very minute amount. Lead affects several organ systems like hematopoetic system, peripheral and central nervous system, and kidneys [7].

Calcium. The determination of Ca in fresh water is important since Ca salts in water very often cause the hardness, scale formation and impart corrosive properties. The concentration of $\mathrm{Ca}$ in raw and treated water is found to be 0.74 and $10.19 \mathrm{ppm}$. Which is very low compared to IS and international standards (Table 4). Usually there is no known bad effect of calcium when it is slightly higher except in some cases kidney stone has been reported. This element became the "miracle" mineral of the 1980s with consumers increasing their intake in the hope of preventing osteoporosis and lowering blood pressure [2].

Magnesium. Just like calcium, Mg also causes hardness, scale formation, and corrosive properties of water. The concentration of this element in raw water is found to be $1.84 \mathrm{ppm}$ and in treated water it is $3.24 \mathrm{ppm}$. Compared to IS and other standards value (Table 4 ) the water sample contains very low amount of Mg. This element enhances stamina and can help prevent heart disease and hypertension [2].

Potassium. The determination of $\mathrm{K}$ content in fresh and drinking water is important as $\mathrm{K} 40$ is the major source of natural radioactivity found in water. Potassium in raw and treated water is found to be 2.69 and $3.24 \mathrm{ppm}$. The concentration increases after treatment of the water. Potassium maintains the electrolyte balance in blood and body fluids and also releases certain enzymes and hormones that prevent heart failure [2]. There is no specific data for comparison of this element.

The other elements As, $\mathrm{Rb}, \mathrm{Ag}$, and $\mathrm{Au}$ are not detected in all the water samples.

Statistical method of analysis was adopted to determine the relationship between the trace elements in untreated and treated water (Table 5). There was no significant correlation (at $P<0.05$ ). No correlation of nickel and cobalt was observed in treated water with other trace elements while in untreated water, they are highly correlated with other elements. Low positive correlation of $\mathrm{Pb} / \mathrm{Zn}(0.50)$ in treated water was observed and in untreated water (0.52), the concentrations of these two elements decrease after treatment. Strong correlation between $\mathrm{Cd} / \mathrm{Cu}, \mathrm{Cd} / \mathrm{Ca}$, and $\mathrm{Ca} / \mathrm{Cu}$ in treated water indicates that the concentrations of these elements increase which confirmed our results.

It is reasonable to expect seasonal variations in the level of most of the elements in water, due to a number of reasons such as concentration/dilution precipitation and sedimentation, various geographical and geological factors, $\mathrm{pH}$, turbidity, and electrical conductivity. Based on the analytical data, the concentration of Calcium and magnesium were found to be very low. So the concentrations of these elements present in treated water are considered to be deficient. Proper improvement in order to raise the concentrations of $\mathrm{Ca}$ and $\mathrm{Mg}$ is necessary such that they are at the same limit as other international limit. The other elements lithium, cobalt, and potassium could not be compared as there is no available 
TABLE 5: Correlation coefficient between trace elements in untreated and treated water.

\begin{tabular}{lccr}
\hline \multicolumn{1}{c}{ Untreated water } & \multicolumn{2}{c}{ Treated water } \\
\hline $\mathrm{Mn} / \mathrm{Cr}$ & 0.667 & $\mathrm{Cr} / \mathrm{Li}$ & 0.647 \\
$\mathrm{Zn} / \mathrm{Ni}$ & 0.702 & $\mathrm{Mo} / \mathrm{Mn}$ & 0.539 \\
$\mathrm{Se} / \mathrm{Cu}$ & 0.506 & $\mathrm{Cd} / \mathrm{Cu}$ & 0.759 \\
$\mathrm{Mo} / \mathrm{Fe}$ & 0.561 & $\mathrm{~Pb} / \mathrm{Cr}$ & 0.707 \\
$\mathrm{Cd} / \mathrm{Mn}$ & 0.697 & $\mathrm{Ca} / \mathrm{Cu}$ & 0.765 \\
$\mathrm{Cd} / \mathrm{Cu}$ & 0.577 & $\mathrm{Mg} / \mathrm{Li}$ & 0.667 \\
$\mathrm{Ca} / \mathrm{Na}$ & 0.585 & $\mathrm{Mg} / \mathrm{Cr}$ & 0.518 \\
$\mathrm{Ca} / \mathrm{Co}$ & 0.530 & $\mathrm{Cd} / \mathrm{Se}$ & 0.576 \\
$\mathrm{Mg} / \mathrm{Mn}$ & 0.595 & $\mathrm{~Pb} / \mathrm{Zn}$ & 0.500 \\
$\mathrm{Mg} / \mathrm{Ni}$ & 0.526 & $\mathrm{Cd} / \mathrm{Ca}$ & 0.790 \\
$\mathrm{~Pb} / \mathrm{Zn}$ & 0.523 & $\mathrm{~K} / \mathrm{Mo}$ & 0.557 \\
$\mathrm{Ca} / \mathrm{Zn}$ & 0.549 & $\mathrm{~K} / \mathrm{Ca}$ & 0.550 \\
$\mathrm{~K} / \mathrm{Mg}$ & 0.635 & $\mathrm{~K} / \mathrm{Mg}$ & 0.558 \\
$\mathrm{Co} / \mathrm{Mn}$ & -0.700 & & \\
$\mathrm{Ni} / \mathrm{Li}$ & -0.633 & $\mathrm{Cu} / \mathrm{Fe}$ & -0.784 \\
$\mathrm{Ni} / \mathrm{Na}$ & -0.604 & $\mathrm{Cd} / \mathrm{Fe}$ & -0.703 \\
$\mathrm{Cu} / \mathrm{Cr}$ & -0.776 & $\mathrm{Cd} / \mathrm{Na}$ & -0.701 \\
$\mathrm{Cu} / \mathrm{Co}$ & -0.745 & $\mathrm{Na} / \mathrm{Ca}$ & -0.784 \\
$\mathrm{Zn} / \mathrm{Mn}$ & -0.740 & $\mathrm{Na} / \mathrm{K}$ & -0.823 \\
$\mathrm{Cd} / \mathrm{Co}$ & -0.691 & $\mathrm{Ca} / \mathrm{Zn}$ & -0.612 \\
$\mathrm{Mg} / \mathrm{Fe}$ & -0.837 & $\mathrm{Mg} / \mathrm{Se}$ & -0.994 \\
$\mathrm{Mg} / \mathrm{Co}$ & -0.640 & $\mathrm{Mg} / \mathrm{Cd}$ & -0.637 \\
$\mathrm{~Pb} / \mathrm{Mo}$ & -0.765 & & \\
$\mathrm{~K} / \mathrm{Se}$ & -0.639 & & \\
\hline
\end{tabular}

data for comparison. The elements $\mathrm{Cr}, \mathrm{Co}, \mathrm{Ni}, \mathrm{Zn}, \mathrm{Mo}$, and $\mathrm{Pb}$ concentrations decrease after treatment, especially Zinc which is found to be far below the standard level. The concentrations of $\mathrm{Cr}$ and $\mathrm{Pb}$ should be checked as these are very toxic and harmful from human health point of view. The other elements $\mathrm{Mn}, \mathrm{Cu}$, and $\mathrm{Cd}$ concentrations increase after treatment. Thorough investigations should be carried out for $\mathrm{Cd}$ and $\mathrm{Cu}$ which are toxic metals as these elements can cause a detrimental health hazard. This increase in concentrations may have come from the impurities of the chemicals used to treat the water. The concentration of iron falls within the limit which is considered safe for drinking water. Iron and manganese problems occur in lakes and reservoirs where anaerobic conditions reduce $\mathrm{Fe}^{3+}$ and $\mathrm{Mn}^{4+}$ to soluble $\mathrm{Fe}^{2+}$ and $\mathrm{Mn}^{2+}$ forms. In water column, these elements cause problems for the treatment plant due to increased levels of color, turbidity, and organic matter. Normally they are removed by oxidation. Sufficient dose of chlorine which is used in almost all water plants as final disinfectant to kill organisms before discharging treated water to the distribution system is also used to oxidize other material such as Fe and Mn compounds. However, there is increased evidence for an association between rectal, colon, and bladder cancer on consumption of excess chlorinated drinking water. The element Se is found to be in high concentration. This is expected as the concentration of this element in the soil is very high and it leaches into the river through precipitation as it is present in the soluble form. This element may cause chronic toxicity (longer term) on human health due to frequent exposure to small amounts. The benefit of this element is that it acts as an antioxidant. Detailed study of this element will be carried out in future and its effects on human health and environmental contaminants. Moreover, some new technological methods for removal of trace elements like distillation, ion-exchange, reverse osmosis, and activated carbon filtrations should be adopted to remove excess of selenium and other toxic metals which are unsafe for human health.

The elements Fe, Cr, $\mathrm{Zn}, \mathrm{Mn}, \mathrm{Co}, \mathrm{Pb}$, and $\mathrm{Ni}$ should be monitored carefully on a daily basis. Care should be taken that no metallic pollution of fresh waters takes place as it poses to be a potential health hazard which may come from large scale discharge of industrial effluents into the rivers. Therefore, a periodic check of the fresh waters for major and trace elements is highly recommended. This is very necessary with regard to certain elements of toxicological importance such as cobalt, chromium, selenium, cadmium, copper, iron, nickel, and lead which may also create environmental problems.

\section{Conclusion}

The knowledge of the distribution of trace elements in drinking water serves as the basic information for the future researchers to select the elements for controlled study and in establishing their critical limits. This will surely help to have a better idea in taking further steps for possibly enhancing the quality of drinking water in the state. A comparison of the value obtained with the critical values available helps one to have more insight of the problem. The result suggests the needs for close monitoring of these trace elements in drinking water and improves the water quality in the state so that the water reaching our home must be crystal clear and safe to drink. Many of environmental health problems are the result of long-term, low-level exposure to heavy metals as drinking water plays a key role in environment-human health interactions. Statistical analysis of the trace elements also shows that certain toxic elements like $\mathrm{Cu}, \mathrm{Cd}$ which can cause damages to human health have a strong positive correlation with other elements. So, the increase of one element may increase the concentration of other element in treated water. Constructed wells should be properly located for best sources of water for domestic use which is less likely to be contaminated than water from surface sources like streams, lakes, and ponds as these are almost contaminated and require proper treatment for domestic use. High accumulation of these metals can be released into the aquatic environment as a result of leaching from bedrocks, atmospheric deposition, water drainage, overflow from riverbanks, and discharge of urban and industrial wastewaters. Many of heavy metals are among the most persistent of pollutants in the aquatic ecosystem because of their resistance to decomposition in natural conditions. Treatment systems should be checked routinely to detect possible problems and further development of the guidelines to ensure the quality of water as a source for drinking. 


\section{Conflict of Interests}

The authors declared that they have no commercial conflict of interests related to this work.

\section{Acknowledgments}

The authors wish to thank the University Grant Commission (UGC) for funding this research project and the Head, S.A.I.F., N.E.H.U., Shillong, for allowing them to use their facilities to carry out the work.

\section{References}

[1] J. Rubin, Springs of Life. Garden of Life, 2003.

[2] A. V. Wiesenberger, The Influence of Minerals in Water. Excerpted from "The Taste of Water", 2001.

[3] Public Water Supply Distribution Systems, Assessing and Reducing Risks First Report, The NAS, Washington, DC, USA, 2005, http://www.nap.edu.

[4] Manual AAS vario 6, Cook Book for Selected Elements. WinAAS Versions 3.10, Analytik Jena, 6th edition, 2000.

[5] J. H. Lazarus, "The effects of lithium therapy on thyroid and thyrotropin-releasing hormone," Thyroid, vol. 8, no. 10, pp. 909913, 1998.

[6] WHO, Guidelines for Drinking Water Quality: Health Criteria and Other Supporting Information, World Health Organisation, Geneva, Switzerland, 1993.

[7] V. ValKovic, Analysis of Biological Materials for Trace Elements Using X-Ray Spectroscopy, CRC press, 1983.

[8] H. Rabinovitz, "Washington (reuters health)," in Proceedings of the Meeting of the Technical Factsheet on Chromium-Causes Skin Irritation or Ulceration, November 2000.

[9] C. L. Keen and R. M. Leach, "Manganese," in Handbook on Toxicology of Inorganic Compounds, H. G. Seiler and H. Sigal, Eds., pp. 405-415, Marcel Dekker, New York, NY, USA, 1988.

[10] C. Brandsch, R. Ringseis, and K. Eder, "High dietary iron concentrations enhance the formation of cholesterol oxidation products in the liver of adult rats fed salmon oil with minimal effects on antioxidant status," Journal of Nutrition, vol. 132, no. 8, pp. 2263-2269, 2002.

[11] J. Neve, "The nutritional importance and pharmacological effects of cobalt and vitamin B12 in man," Journal de Pharmacie de Belgique, vol. 46, no. 4, pp. 271-280, 1991.

[12] B. Buzadzic, B. Korac, T. Lazic, and D. Obradovic, "Effect of supplementation with $\mathrm{Cu}$ and $\mathrm{Zn}$ on antioxidant enzyme activity in the rat tissues," Food Research International, vol. 35, no. 2-3, pp. 217-220, 2002.

[13] P. S. Dkhar, Spectroscopic studies of the trace elements on rice, Oryza Sativa. linn. in Meghalaya [Ph.D. thesis], North Eastern Hill University, Shillong, Meghalaya, 1996.

[14] E. Haas, Staying Healthy with Nutrition, 1992.

[15] R. Chakraborty, S. Dey, P. S. Dkhar et al., "Determination of few heavy metals in some vegetables from north eastern region of India in relation to human health," Pollution Research, vol. 23, no. 3, pp. 537-542, 2004. 



\section{Carbohydrate} Chemistry

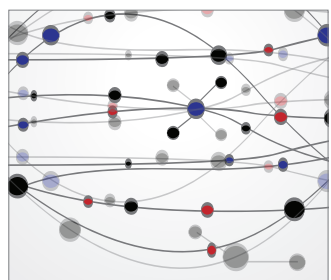

The Scientific World Journal
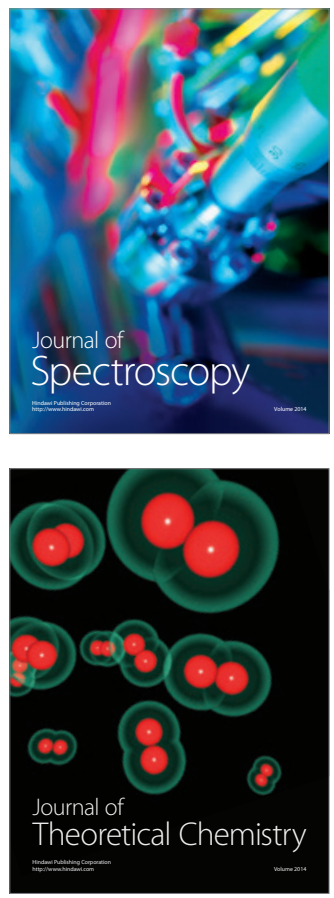
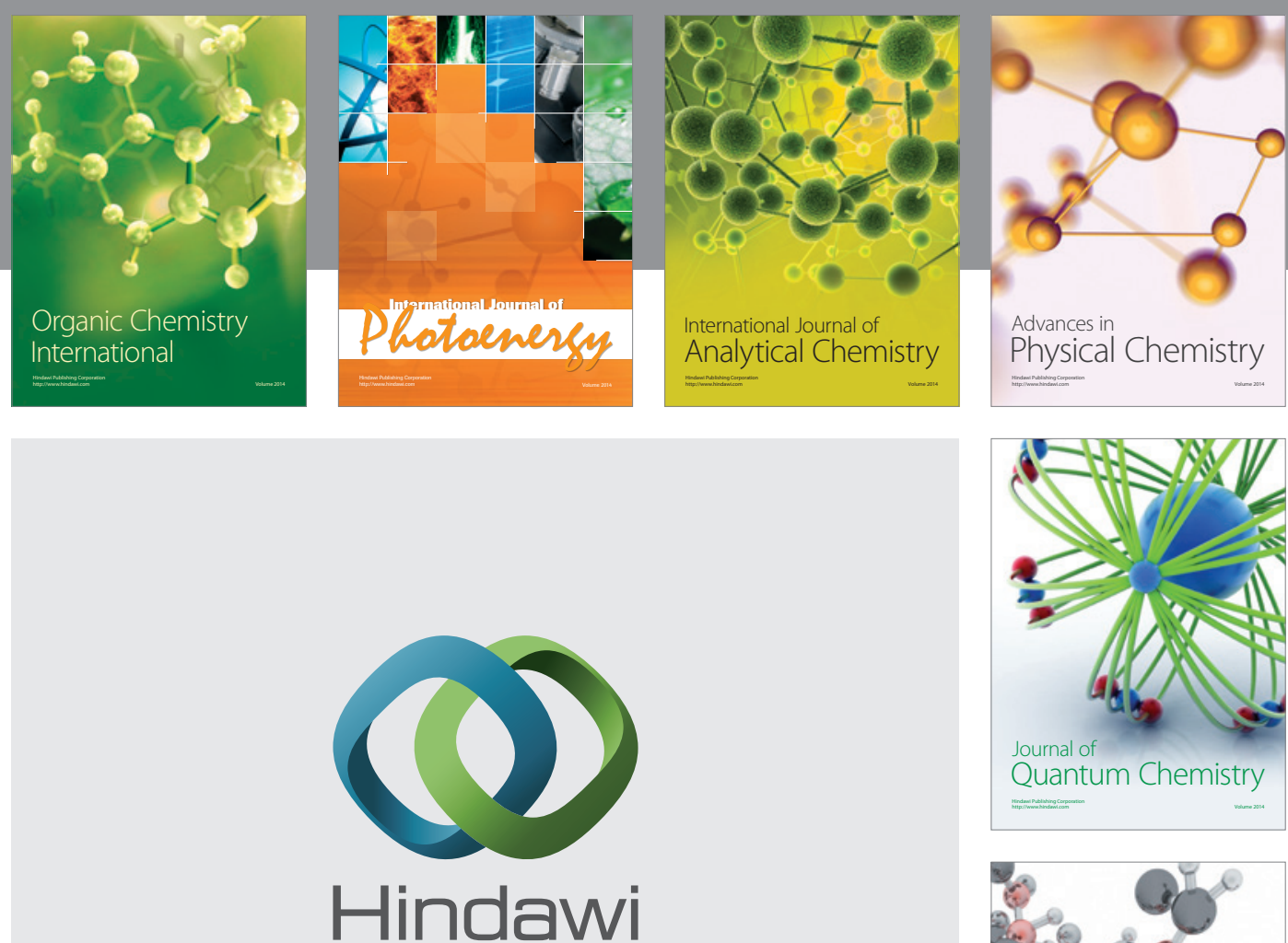

Submit your manuscripts at

http://www.hindawi.com



Analytical Methods

in Chemistry

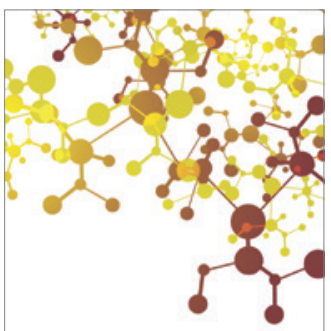

Journal of

Applied Chemistry

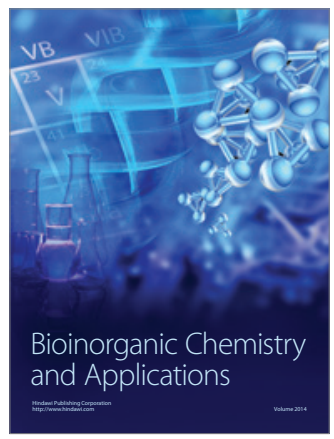

Inorganic Chemistry
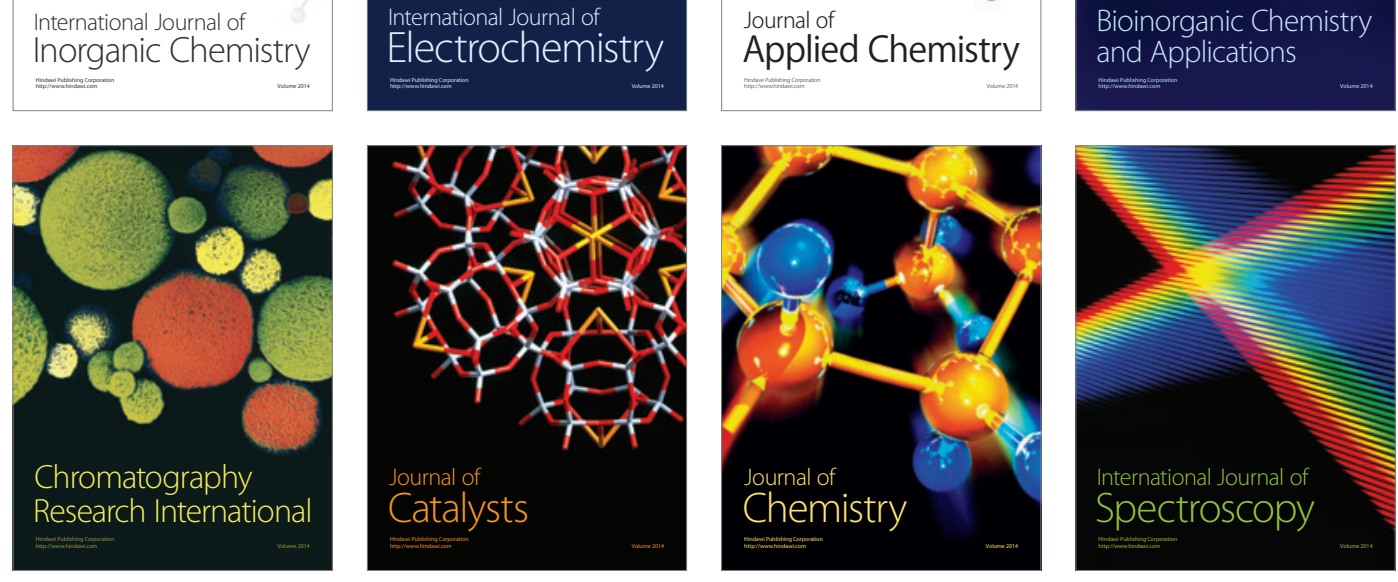